\title{
SCORCHED EARTH: THE USE OF RESTRICTIVE COVENANTS TO STIFLE COMPETITION
}

\section{Bruce Ziff* Ken Jiang**}

Restrictive covenants running with freehold land are sometimes used as a means of impeding commercial competition. For example, when a firm elects to relocate a retail operation and sell the existing site, a covenant may be placed on the title to that site designed to prohibit a competing retail business from operating on those lands. It is known, for example, that the multinational grocery chain Safeway has adopted this practice extensively in Edmonton. Likewise, the practice is found in other Canadian and American cities, in relation not only to grocery stores, but also concerning a range of other retail businesses. Still, little is known about the extent to which covenants are used in this manner.

This article contains an empirical inquiry into the use of covenants in a commercial setting in Edmonton, Alberta. It also explores the manner in which the law responds, and should respond, to mediate public values and private interests within this context.

Les clauses restrictives qui accompagnent les fonds francs sont parfois utilisées pour entraver la concurrence commerciale. Par exemple, lorsqu'une entreprise choisit de déménager une activité de détail et qu'elle vend l'emplacement existant, le titre de propriété des lieux peut être assorti d'une clause restrictive visant à empêcher un commerce de détail concurrentiel de faire des affaires sur les lieux mêmes. On sait, par exemple, que la chaîne de supermarchés multinationaux Safeway a eu amplement recours à cette pratique à Edmonton. On retrouve également cette pratique dans d'autres villes canadiennes et américaines, non seulement en ce qui concerne les épiceries, mais en ce qui concerne une gamme de commerces de détail. Malgré cela, on a très peu idée de la mesure dans laquelle ces clauses restrictives sont utilisées de cette manière.

Le présent article contient une enquête empirique sur l'utilisation des clauses restrictives dans un contexte commercial à Edmonton, en Alberta. Il explore également la manière dont le législateur réagit, et devrait réagir, pour

* Bruce Ziff, Faculty of Law, University of Alberta

** Ken Jiang, LL.B. University of Alberta, 2012. We are grateful to the University of Alberta for providing funding for this project, and to Christine Bremner for her assistance. 
concilier les valeurs publiques et les intérêts privés dans ce contexte.

\section{INTRODUCTION}

Restrictive covenants annexed to freehold land have been recognized as valid for over 150 years. During that time they have proven to be highly useful in a large range of conveyancing settings. By definition, these covenants can restrict the development of land, and so can serve as a rudimentary means of environmental protection. Indeed the landmark decision of Tulk $v$ Moxhay (1848) ${ }^{1}$ conventionally taken as the starting point for the law of freehold covenants -involved just such a restriction. Today these private planning tools are invoked to do far more.

Covenants have been used to facilitate the development of planned residential communities. For example, about a century ago Charles Carruthers subdivided a large parcel of land into dozens of lots in the centre of Edmonton, Alberta. On each parcel he imposed restrictions designed to preserve the neighbourhood for single family dwellings only. All this time later, the "Carruthers Caveat" (as it is called) remains in force. ${ }^{2}$ Similar examples can be found in municipalities across Canada. In new residential developments covenants control what may or may not be placed on lawns, driveways, backyards and so forth. Business activities may be restricted or forbidden altogether in these neighbourhoods. Both the benefits and burdens of these local laws may be attached to every lot within the development, so that each owner may enforce, but is subject to, the same set of rules.

Covenants are also used in connection with commercial properties. While homogeneity (conformity) is often the object of residential covenant plans, the objective in the commercial realm is often the reverse -- heterogeneity. A developer might seek to control the overall mix of retail offerings within a shopping mall. One means of doing so is the imposition of restrictions in leasehold or freehold transfers. ${ }^{3}$ Moreover, covenants are also used to protect stand-alone retail businesses. Consider the following example. A large supermarket chain operates several stores in a given locale. At some point a decision is made to relocate one of these retail outlets, owing to lagging sales, the need for additional space, etc. At the same time, there may be a concern that the old location might be acquired by a competitor firm. One method of preventing that result is to annex to the property a covenant that the land shall not be used as a supermarket. Properly drafted, such a promise would bind the new owner, all subsequent owners, and any lessee of the property.

1 (1848) 2 Ph 774, 41 ER 1143. See also SI George, "Tulk v Moxhay Restored - to its Historical Setting" (1990) 12 Liverpool L Rev 173; JC Smith, "Tulk v Moxhay: The Fight to Develop Leicester Square" in G Korngold \& AP Morriss, eds, Property Stories, 2nd ed (New York: Foundation Press, 2009) 171; B Ziff, "Bumble Bees Cannot Fly: And Restrictive Covenants Cannot Run", forthcoming.

2 See Tanti v Gruden, 1999 CarswellAlta 395 (WL Can), [1999] 11 WWR 294 (CA). In 1920s, the Hudson's Bay Company imposed a similar scheme on a large swath of its reserve lands. See Seiffeddine v Hudson's Bay Traders, 1980 CarswellAlta 2 (WL Can), 108 DLR (3d) 671 (CA).

3 See further, FW Woolworth $v$ Hudson's Bay Co, 1985 CarswellNB 169 (WL Can), 158 APR 403 (CA); Re Spike \& Rocca Group Ltd, 1980 CarswellPEI 100 (WL Can), 29 Nfld. \& PEIR 1 (SC); Russo v Field, [1973] SCR 466, 1973 CarswellOnt 223 (WL Can). 
The use of covenants is not without controversy. There was a period during which restrictions were used as a tool of racial and religious discrimination. In communities such as Westdale in Hamilton one might find registered on dozens of titles a covenant prohibiting the sale or occupation of a property by persons of specified racial, national or religious affiliation. Those covenants are no longer valid. ${ }^{4}$ On a general plane, a covenant can allow a former owner to control the use of lands for decades. It is an extremely durable form of dead hand control, as the Carruthers Caveat illustrates. Furthermore, private covenants can subvert public policy initiatives. ${ }^{5}$ For instance, a zoning ordinance might allow for the use of lands for a group home, an AIDS hospice, or multi-family dwellings, but a covenant on land within that zone may validly preclude those uses.

In addition, this kind of private zoning is largely hidden from view. Municipalities must publish zoning by-laws in the ordinary course of public administration, and the precise boundaries of the zones are discernible on a cadastre. There is no easily accessible record for restrictive covenants. Although a restrictive covenant must normally be recorded on title to be binding against a new owner of land, there is no cadastre denoting where any of these are situated. Instead, the presence or not of a covenant can be discovered only by searching individual titles, one-by-one.

In this paper, our focus is on one of the controversial uses of restrictive covenants, that is, their use as a means of stifling retail competition. That practice as it concerns supermarkets (mentioned above) has fallen under scrutiny because of the impact that it can have on some neighbourhoods. In recent years, urban geographers have been concerned with the creation in various cities of what has been termed "food deserts". ${ }^{6}$ These are areas in a city within which access to healthy foods is limited. The problem is especially acute in low-income communities. The presence of a covenant preventing an otherwise ideal site from being used as a grocery store can contribute to the emergence or continuation of a food desert.

Questions inevitably emerge as to the legality of this kind of covenant, the mechanisms of terminating otherwise valid restrictions, and the policy factors that might impel such action. Furthermore, these issues may be germane in other retail sectors. While non-compete covenants for supermarkets have come to public attention, less is known about their use in other commercial contexts. In this paper we address these matters. First, we will outline the findings of a modest investigation of restrictive covenants in Edmonton, Alberta. Attention then turns to the elements of validity and the bases upon which restrictions may be challenged. Of particular importance here is the issue of whether the restraint of trade imposed in these documents conflicts with the public interest.

4 See further, Ziff, supra note 1.

5 See further, P Filion, The Impact of Restrictive Covenants on Affordable Housing and Non-SingleFamily Uses of Homes: A Waterloo Region Case Study (Ottawa: Canadian Mortgage and Housing Corporation, 1993).

6 See e.g., K Larsen \& J Gilliland, "Mapping the Evolution of 'Food Deserts' in a Canadian City: Supermarket Accessibility in London, Ontario, 1961-2005" (2008) 7 International Journal of Health Geographics 16; H Shaw, "Food Deserts: Towards the Development of a Classification" (2006) 88 Human Geography 231. 


\title{
II. COVENANT SPECIMENS
}

There is virtually no published data on the uses of restrictive covenants in Canada. ${ }^{7}$ In this paper we provide a modest empirical contribution through a review of covenants that are registered on title to properties in the city of Edmonton. All of these documents contain some form of anti-competition restriction. Our goal was to collect specimens that would reveal the variety of uses found in the wild.

About 50 covenants were initially examined, and with these in hand, we attempted to assess the breadth of usage across retail sectors, look for common modes of drafting, and, importantly, address whether the validity of any of the covenants collected could be challenged. From that larger pool, we selected 22 documents for further analysis. The contents of those specimens are summarized in a table that appears in an appendix to this article. Because the sample is not large and not strictly random, we resist making strong empirical claims about overall trends and patterns. Each of the documents summarized contains unique features, although, as will be seen, there is some overlap. From the original 50 documents the most common restrictions related to service stations and grocery stores; only one of each appears in the appendix.

The samples revealed considerable diversity in both the substance and form. If there is a standard practice in the creation and use of covenants regulating retail trade in Edmonton, it was not apparent from the documents under study. Consider first the kinds of retail businesses affected. These can be collected under five headings: covenants relating to (i) food and drink; (ii) entertainment; (iii) durable goods; (iv) automotive products and services; and (v) other services (loosely defined). Below is a more detailed breakdown:

\author{
(i) Food and Drink \\ Grocery store/supermarket \\ Bakery \\ Meat market \\ Delicatessen \\ Liquor store \\ Liquor lounge \\ Sandwich shop \\ Yoghurt shop \\ Convenience store \\ Pizzeria \\ Restaurant \\ Donut shop \\ (ii) Entertainment \\ Cinema \\ Porn shop \\ Casino \\ Video arcade \\ (iii) Durable Goods \\ Furniture store
}

$7 \quad$ But see Filion, supra note 5. 
Electronics store

Department store

Hardware store (including garden centre)

(iv) Automotive

Muffler/brake shop

Gas station

(v) Other Services

Bank, trust company, caisse populaire, etc.

ATM

Only as a hotel or motel

As will be explained more fully, a restrictive covenant requires that at least two properties be involved. In brief, a restriction is imposed on one property, which is said to be burdened by the promise. Borrowing from the lexicon of the law of easements, that parcel is sometimes described as the servient tenement. The covenant must also be shown to benefit some other parcel. This benefited land is likewise referred to as the dominant tenement. In a majority of the documents, there was one dominant and one servient tenement (and those labels were pervasively used). However, beyond that there were many variations: either multiple dominant tenements, multiple servient tenements, or both (see the appendix).

The apparent circumstances under which the covenants were imposed also varied greatly. In most instances, the standard paradigm held: on the sale of Lot 1, a covenant was annexed that was designed to benefit Lot 2, which is either adjacent or relatively nearby. In some cases, the purchaser exacted a covenant from the vendor. In other words, the deal was that the purchaser would acquire land provided that the vendor agreed that one or more other properties would never be used for a competitor business. In two instances, leasehold properties were involved; in one case as a dominant tenement, in the other as the servient lands.

The duration of the covenants varied considerably. All else being equal, a restrictive covenant is capable of remaining in force indefinitely. Three approaches were evident. In some, a specific time period was set out, ranging from 10 to 40 years. Alternatively, the duration was fixed by a formula. The most common approach was to state that the restriction was to remain in place on the servient property so long as the dominant tenement was being used for $\mathrm{X}$ purposes, that purpose being the same as the prohibited use imposed on the servient land. ${ }^{8}$ The remaining covenants do not specify a time-limit.

8 The most unusual time stipulation, found in a 1997 covenant, defined the term of the restriction to be "fifty years after the date of death of the last surviving heir of His Majesty King George VI". This is a form of "royal lives clause", which developed in England as a means of avoiding violations of the rule against perpetuities. However, in order to conform to that rule, the clause must specify heirs then living, which is not so here. As drafted the covenant is capable of remaining in place as long as the line of heirs continues from generation to generation. I doubt that that was the intention of the draftsperson. 


\section{LEGAL ISSUES}

\section{A. Introduction}

Covenants are designed to advance private commercial interests, and in doing so some aspect of the public interest may be sacrificed. The market is premised on healthy, free, and vibrant competition, yet by definition the covenants studied here impede competition with the result that consumer choice is constricted to some degree. As noted above, these concerns have bubbled up in Canada in relation to supermarkets. Our modest study suggests that the problem may run deeper.

Those who have become concerned with the adverse effects of covenants have questioned their legality. In essence, there are three facets of the validity question. First, there are certain essential structural features of a restrictive covenant, and the absence of any one of these means that the covenant is incapable of running with the servient land and thereby binding new owners. Second, there are requirements that apply to all private transactions, including covenants, so that even where the four structural requirements are met, the covenant may be defective on one of these exogenous bases. Third, there are means by which a covenant that is otherwise valid may nevertheless be terminated prematurely. Each of these three categories will be considered in turn.

\section{B. Structural Requirements for Restrictive Covenants ${ }^{9}$}

There are four main requirements of a restrictive covenant under modern Canadian law. First, the covenant must be negative in substance. In other words, a covenant may seek to prevent or restrict certain activities on the land, but it cannot compel action. ${ }^{10}$ Second, it must have been intended that the covenant would run with the affected parcel. ${ }^{11}$ Third, for the covenant to be effective, a purchaser must have been given appropriate notice of its existence. Fourth, as already alluded to there must be some other identified ${ }^{12}$ property (the dominant tenement) that is intended to, and capable of, being benefited by the restriction.

The documents within our sample reveal no difficulties whatsoever with the first three prerequisites. The covenants meet the negativity requirement perfectly. Each one seeks to prevent certain business activities, but compels nothing. All of the covenants expressly state that the covenant is designed to run with the servient land. And notice is perfected by registration. Alberta operates a Torrens title system under which there is strict adherence to the so-called mirror principle. An interest in land will not be valid against a subsequent purchaser of the land unless it is appropriately noted on title. In other words, notice outside of the register is not effective. ${ }^{13}$ At the same time, the covenant is registered for what it is worth,

See further B Ziff, Principles of Property Law, 5th ed (Toronto: Carswell, 2010) at 405 et seq. See Amberwood Investments Ltd v Durham Condominium Corp No 123, 2002 CarswellOnt 850, and the authorities cited there.

11 See Dundee Realty Corp v Harvard Developments Inc, 2011 SKQB 74, 2011 CarswellSask 115(WL Can), and the authorities cited there. See also Qureshi v Gooch, 2005 BCSC 1584, 2005 CarswellBC 2707(WL Can).

12 Galbraith v Madawaska Club Ltd, [1961] SCR 639, 1961 CarswellOnt 72(WL Can) [Galbraith]. See also Lindner v Chittick, 2010 CarswellAlta 2490(WL Can), 2010 ABQB 819, and the authorities cited there.

13 See Holt Renfrew \& Co v Henry Singer Ltd (1982) 135 DLR (3d) 391, 1982 CarswellAlta 92 (WL Can) (CA) leave to appeal to SCC refused (1982) 22 AltaLR (2d) xxxvi. 
standing or falling under the substantive law. In other words, a properly registered covenant may nevertheless be invalid.

The fourth criterion, and in particular the principle that the dominant lands must be capable of being benefited by the restriction, requires a more detailed analysis. What does it mean to say that a promise made in relation to one parcel must enure to the benefit of some other land, and what function does that prerequisite serve? These questions lie at the heart of the modern covenant concept, and to resolve them requires one to draw back to first principles.

It was not initially essential that a promise affecting a servient property benefit some other land. In Tulk $v$ Moxhay ${ }^{14}$ the Chancellor stressed merely that the purchaser acquired the burdened lands with knowledge of the restriction. There was no mention of the necessity of a benefited property, though as it turns out, there were nearby lots owned by the covenantee that could benefit from the promise. The requirement that there be a dominant tenement was not established in English law until $1914^{15}$ and Canadian cases followed suit shortly afterwards. ${ }^{16}$ In Canadian law it is said that the benefit must "touch and concern" a dominant property. $^{17}$

The rationale for mandating that there be a dominant land is not free from doubt, and the cases shed little light on that point. The rule might serve as a proxy for the idea that a covenant should only be enforceable when the holder of the benefit has a legitimate interest in seeking enforcement. ${ }^{18}$ It also allows the holder of the benefit to be readily identified. The owner of that land is entitled to enforce (or waive) the restriction. Moreover, the requirement can work as a partial hedge against overburdening the servient lands, since the need for the covenant to benefit some other property can reduce the number of parties capable of holding the benefit. $^{19}$

What constitutes a true benefit is likewise obscure. The "touch and concern" phrase adds little clarity on its own. More helpful, but only slightly so, is the idea that the promise either affect the dominant land as regards (i) the mode of occupation or (ii) it must per se, and not merely from collateral circumstances, affect the value of that land. That word recipe was adopted by the Supreme Court of Canada over 50 years ago as setting the appropriate standard. ${ }^{20}$

$14 \quad$ Supra note 1.

15 London County Council v Allen, [1914] 3 KB 642 (CA). See further Anzco Foods Waitara Ltd v Affco New Zealand Ltd, [2006] NZLR 351 (CA).

16 Re Hunt \& Bell (1915) 24 DLR 590 (Ont CA); Anderson v Moran, [1928] 2 WWR 307, 1928 CarswellAlta 20 (WL Can) (S C App Div).

17 See e.g. Galbraith, supra note 12.

18 K Gray \& S Francis Gray, Elements of Land Law, 5th ed (Oxford: Oxford University Press, 2009) at 266 .

19 WF Depoorter \& F Parisi, "Fragmentation of Property Rights: A Functional Interpretation of the Law of Servitudes" (2003) 3 Global Jurist Frontiers, art 2. See also Note, "Touch and Concern, The Restatement (Third) of Property: Servitudes, and a Proposal”, (2009) 122 Harv L Rev 938 at n14 (summarizing other claims about the function of the requirement).

20 Galbraith, supra note 12, at 20, quoting Rogers v Hosegood, [1900] 2 Ch 388, at 395. See also Canadian Construction Co v Beaver (Alberta) Lumber Ltd, [1955] SCR 682, 1955 CarswellAlta 80 (WL Can); PMT XII LLC v Strata Plan VR 2753, Section 1, 2010 CarswellBC 2314 (WL Can) (SC). 
For the covenants in our study to be valid, non-competition covenants must, in principle, be able to satisfy touch and concern requirement. In a 19th century Massachusetts case, Norcross v James, Justice Oliver Wendell Holmes denied that such covenants could pass muster on that basis. ${ }^{21}$ At issue was a restriction that prohibited the servient lands from being used as a quarry. The adjacent dominant tenement was being used for that purpose. When the servient land was transferred, the validity of the restriction was successfully challenged. Holmes J held that the covenant "simply tend[ed] indirectly to increase [the dominant tenement's] value, by excluding a competitor from the market for its products." ${ }^{22}$ Moreover, denying the extension of the doctrine to cover competition was seen as consonant with the general policy of limiting the creation of unusual incidents of property. Norcross represented the law in Massachusetts for almost 90 years. ${ }^{23}$

There is a clean logic to the approach taken in Norcross. The restriction was seen as relating only to the business and not to the land. However, it is not hard to blur that line, as the following examples illustrate. A developer might wish to restrict all or virtually all business activities as a means of preserving the integrity of a residential neighbourhood. One can appreciate that such a restriction affects both the mode of occupation and the desirability (value) of the property as a residence. Location is a key element in the decision of would-be homeowners. Even within a commercial area, one might wish to restrict certain uses because they produce a noxious physical environment. A perfume store would benefit from a covenant prohibiting a neighbouring property from being the site of a paper mill.

If it is accepted that such covenants fit within the touch and concern concept (and if they do not, what would?), then one can move a little further along the spectrum. The covenant protecting the physical environment in the last example is designed to prevent customers from being driven away. Along the same lines, one might wish to prevent some kinds of businesses from locating near the dominant lands because of a similar concern about the loss of clientele. For instance, a store selling children's toys would benefit from a covenant that prohibited certain adultoriented stores on nearby lots. In our study, one covenant precluded the use of lands for the sale of pornography, and another prevented casino or gaming businesses. In each case the goal might have been to preserve the character of the shopping district.

It is a very short step from the last example to that of a garden-variety noncompetition restriction. And although one can argue that it is a false step, it is one that has been taken in Canada ${ }^{24}$ and elsewhere. That is now even true in Massachusetts, where Norcross $v$ James has been overruled. ${ }^{25}$ This position seems

21 Norcross $v$ James, 2 NE 946 (Mass SC, 1885).

22 Ibid at 949 (per Holmes J).

23 See Shade v M O'Keeffe, Inc, 156 NE 867 (Mass SC, 1927), and Shell Oil Co v Henry Ouellette \& Sons, Inc, 227 NE 2d 509 (Mass SC, 1967). See contra Whitinsville Plaza, Inc v Kotseas, 390 NE 2d 243 (Mass SC, 1979) [Kotseas]. See also Bennett v Commission of Food and Agricultures, 576 NE 2d 1365 (Mass SC, 1991) (abolishing the touch and concern requirement altogether and adopting the approach found in Restatement (Third) of Property: Servitudes (2000).

24 Bowes Co v Rankin, [1924] 4 DLR 406 (Ont CA); Miller v Shell Canada Ltd, 1985 CarswellSask 224 (WL Can), [1985] 6 WWR 631 (QB) [Bowes]. See also Canada Safeway Ltd v Thompson (City), 1997 CarswellMan 256 (WL Can), 118 Man R (2d) 34 (CA); Newton Abbot Co-Operative Society Ltd $v$ Williamson \& Treadgold Ltd, [1952] 1 Ch 286.

25

Kotseas, supra note 23. 
to have been accepted in these jurisdictions with very little attention to how it might affect the ambit and impact of the doctrine.

The validity of non-competition covenants places great strain on another aspect of the touch and concern concept. Not only must there be a dominant and a servient tenement for covenants to run with land, but also those two properties must be physically proximate. They need not be contiguous to satisfy this requirement, and there is also no fixed maximum allowable spatial separation. In many instances the nature of the promise provides some guidance as to the appropriate degree of proximity. For example, a covenant aimed at preventing noxious uses can be seen as benefiting any land that would otherwise be affected in an appreciable way by such uses. However, a non-compete covenant has a far more abstract quality. It can, in appropriate situations, have a far greater territorial scope.

There are few reported decisions on point, from Canada or elsewhere, on the proximity requirement in general, and its application to non-compete covenants in particular. ${ }^{26}$ As a result, the parameters of the doctrine are indeterminate. The paucity of case law is not surprising. Although it appears that the use of restrictive covenants to inhibit competition is found in a number of commercial realms, there is rarely an incentive on the part of would-be purchasers to challenge the validity of a restriction. Why mount an assault if there are ample alternative business sites? Of course, the existence of other suitable properties underscores the argument that the covenant does not confer a real benefit on the dominant land, suggesting that a challenge might well succeed on that ground. At the same time, a rival business might not wish to invalidate the restriction even ignoring the time, expense and uncertainty surrounding that kind of legal action. After all, that firm might want to free-ride on the restriction by locating near to the restricted parcel, since it is likely that a competitor will not try to set up shop on the restricted site.

There are two relatively recent Canadian decisions that provide some guidance. In the first of these, Swan Properties Ltd $v$ Irving Oil, ${ }^{27}$ a covenant was annexed on a vacant lot in the town of Clarenville, NL (population 6,000), prohibiting inter alia the use of the land as a restaurant and for the sale of "confectionary" products. Swan purchased that land as a site for an office tower. When that plan fell through, it decided to use the lot for retail purposes, and to lease units to an A\&W franchise and to a business called the Movie Gallery. It was accepted that the operations of both tenants would contravene the covenant. (In the case of the Movie Gallery, the breach would presumably arise from the sale of confections.) The covenant had been taken for the benefit of twelve dominant tenements. Two were in Clarenville and the remaining ten were in other communities in eastern Newfoundland. On one of the Clarenville properties, Irving operated a business called Big Stop, which included a full-service restaurant in connection with a gas station. The

26 In Jain v Nepean (City), 1989 CarswellOnt 603 (WL Can), 69 OR (3d) 353 (HC), a covenant affecting (among other things) construction and subdivision of land. The covenant was taken to be for the benefit of land owned by the municipality, in fact, the site of the Nepean city hall, which was about 6 kilometers away. The distance between the two properties was seen to be fatal to the running of the covenant. The decision at first instance was varied on appeal on other grounds: 1992 CarswellOnt 588 (WL Can) , 9 OR (3d) 11 (CA) leave to appeal refused: [1993] 1 SCR ix

272004 NLSCTD 206, 25 RPR (4th) 268. See also Baramon Sales Pty Ltd v Goodman Fielder Mills $L t d$, [2001] FCA 1672, which upheld a covenant preventing the use of land as a flour mill. The dominant land was about 12.5 kilometers away by road. 
servient tenement owned by Swan was $3.8 \mathrm{~km}$ or $5.2 \mathrm{~km}$ away, depending on which of two routes was used.

Swan attacked the covenant on a number of grounds, including a claim based on the lack of proximity. That argument was tersely dismissed. It was said, simply, that there was a limited customer base for restaurants in Clarenville, and that Irving's restaurant business would be adversely affected if competitors entered that market:

The Big Stop property is within the same town and can be reached by short drives of 3.8 or $5.2 \mathrm{~km}$... It is specious to argue that the Big Stop property cannot benefit from the burden placed on the Swan property because they are separated by such short distances. Kevin Harris ... pointed out that the food industry in Clarenville serves a limited clientele which would be depleted to the detriment of the restaurant portion of the Big Stop operations if competitors enter the food service industry in the town.

The Swan case assesses proximity in a straightforward way: in effect a notional competition radius is constructed with the dominant land at its epicentre. The scope of the zone is determined by the likely catchment area for the business in question. In this instance, it was assumed that anyone in Clarenville was a potential patron of the Big Stop restaurant. A servient parcel within the town would therefore fall within the competition radius. Accordingly, it would be sufficiently proximate to provide a benefit to the dominant lands.

A good deal of that reasoning is conjectural. However, there is a deeper problem, as is illustrated by the second case, 880682 Alberta Ltd v Molson Breweries Properties $\mathrm{Ltd}^{29}$ There, the validity of a restrictive covenant annexed to land in Calgary was at issue. The covenant prohibited the use of that land for a brewery and was stated to be taken for the benefit of Molson's Edmonton operation, some 300 kilometers to the north.

Molson marshalled the same kind of argument seen in the Swan case, that is, that owners of the two properties would be competing for the same clients. Molson's Edmonton factory supplied product to Calgary, and indeed throughout Alberta. The covenant pertained to a highly competitive industry, with breweries at 'lagerheads' in an effort to reach the same clientele. Sales by one company are very likely to reduce the sales of another. Accordingly, the brewery facility in Calgary fell within Molson's competition radius. The two plants could be rivals for the same clientele, and therefore Molson's Edmonton operation would benefit from the covenant located in Calgary.

The competition-radius argument failed. The Court observed that "[i]f the principle argued by Molson is allowed to stand, it would not only stand for

$28 \quad$ Supra note 27 at para 71 (per Handrigan J).

$292002 \mathrm{ABQB} 771$. In Bowes, supra note 24, a covenant in the village of Bloomfield, ON

prohibited the use of the servient lands as a cannery. A cannery had operated on that parcel and the lands had been purchased by the covenantee to prevent competition. It operated canneries on two other sites in the village, the output of which, it was claimed, could accommodate all of the produce produced in the vicinity. It was held that the covenant was valid. The restriction would tend to enhance the market value of the dominant lands, but there was no discussion of proximity. One can assume that the community was small enough to satisfy that criterion. 
dominant lands in Edmonton, but potentially anywhere in the world." ${ }^{30}$ As was stressed in argument, such would be the case, for example, if covenants were imposed by Microsoft, with its headquarters serving as the dominant tenement. ${ }^{31}$

The Swan and Molson cases seem to have been rightly decided on their facts. However, both involved, in their own ways, an apparent invasion of the dominant parcel's competitive zone. The difference in outcome was based solely on the extent of separation between the two parcels involved. That being so, if we imagine a string of covenants of the same nature on a continuous swath of land from Calgary to Edmonton, at some point the proximity requirement would presumably be met. One needs to identify a principle that allows that line to be drawn in a rational way.

It must be remembered that proximity is only one component of the rule that the restriction must be capable of benefiting the dominant tenement. But the bar as to what counts as a sufficient benefit in this context appears to be set quite low. A restrictive covenant does very little at the best of times to prevent competition, since it applies only to the named servient tenement(s). One would think that, at the very least, there must be an overlap of competitive zones, for there can be no meaningful benefit if that element is missing. However, that cannot be enough on its own: again, that was present in both Swan and Molson. The existence of a competitive overlap is a necessary but not a sufficient condition to find a true benefit to the dominant territory. Other factors may also be germane.

Principal among these germane factors, we suggest, should be the extent to which the servient lands are able to appropriate some measure of the commercial advantages enjoyed by the dominant lands. A firm will choose to establish a business at a given location after taking into account a number of factors. Variables such as customer traffic, ease of access and parking, the locations of competitor-businesses, the cost of land, and plans for redevelopment in the vicinity, can come into play. When a substantial part of the commercial advantages of the dominant tenement would also enure to a servient tenement, a non-compete restriction may confer a sufficient benefit on the dominant property.

Properties that are adjacent are very likely to meet the commerical-advantges criterion. If the breweries in the Molson case were on adjoining properties one could easily reach that result. One can surmise that the distribution point for beer suppliers matters a great deal to transportation and overhead costs, and so forth. As one moves away from the dominant tenement, certain of those advantages may diminish, weakening the benefit conferred on that tenement by the restriction.

But even where the appropriation of location-based advantages are strong, the benefit may still prove insufficient. That might be true, for example, where there are abundant alternative sites for a competitor business within the competition zone, or where the zone is already saturated with competitors. In either of these situations, the effect of a non-competition covenant would be trivial, and hence undeserving of enforcement as an interest in land.

The following example drawn from the collected specimens allows the problem of assessing proximity to be examined. The covenant quoted below was

$30 \quad$ Ibid at para 24 (per Rooke J).

31 Ibid at para 40, quoting the submission of counsel. Cf. Baramon Sales Pty Ltd v Goodman Fielder Mills Ltd, supra note 27 at para 15. 
registered in $1996 .{ }^{32}$ No period of operation is stated, and the document remains on title. The restriction reads:

The Servient Tenement or any building now or hereafter situated thereon shall not be used, permitted, or suffered to be used for any of the following purposes, without the prior written consent of the Grantee (which consent may be arbitrarily withheld):

a. the purpose of wholesale distribution or retail sale of food, tobacco and liquor for off-premises consumption;

b. the purpose of a retail business consisting of the supply, retail dispensing and compounding of drugs and retail products of the pharmaceutical or therapeutic or hygienic or cosmetic nature or purpose;

c. the purpose of a gas bar or service station or for the retail sale of gasoline and petroleum products; and

d. the purpose of providing a parking lot and or parkade for any establishment located on any other lands which is engaged in the wholesale distribution or retail sale of food, tobacco, pharmacy, drug and automotive fuel products.

The document further provides that these restrictions do not prevent the use of the lands for a "restaurant which sells prepared food for immediate consumption either on or off the premises".

The covenant is imposed on two adjoining lots. Both of these lots house a single building and business, and so in functional terms comprise one servient tenement. There are seven dominant tenements listed. Moreover, the covenant provides that if additional dominant tenements are subsequently acquired while the covenantor is the owner of the servient lands, a restrictive covenant will be granted for the benefit of that after-acquired property.

The driving distances between each of the dominant tenements and the servient tenement are set out in the following table:

\section{Driving Distances from the Servient Tenement 9017 - 111th Ave}

$\begin{array}{lll}\text { 1. } & 14740-111 \text { Ave } & 6.6 \mathrm{~km} \\ \text { 2. } & 9910-69 \text { Ave } & 7.8 \\ \text { 3. } & 16104-121 \text { A Ave } & 13.2 \\ \text { 4. } & 4841 \text { Calgary Trail } & 10.3 \\ \text { 5. } & 12350-137 \text { Ave } & 9.0 \\ \text { 6. } & 17303 \text { Stony Plain Rd. } & 10.5 \\ \text { 7. } & 4950-137 \text { Ave } & 10.7\end{array}$

The main prohibition would appear to be in relation to retail food sales. You will notice that the first dominant tenement listed is the closest, and is on the same avenue (111th), over 50 blocks to the west. One might be prepared to assume that

32 Alberta Land Titles Office, Document \# 962252503. 
somewhere between these two properties one could locate a cohort of families that might tend to choose between these two locations. Currently, there is no grocery store on the servient property (owing to the covenant or not), so one must resort to probabilities, counterfactuals, and possibly expert evidence. Even if one were to assume a meaningful competitive overlap, the issue of the appropriation of location advantages would then arise. For example, both sites might have the benefit of whatever traffic flow is provided along 111th Ave, which is an important artery. However, traffic patterns on that street might vary considerably over a fifty-block span. The other relevant variables would be less easy to discern.

Even if one is able to conclude that the first-listed dominant property is sufficiently proximate, it becomes increasingly difficult to reach the same conclusion for the more remote parcels. Moreover, if one considers some of the other forbidden uses, the proximity element is strained to the breaking point. Consider, for instance, the ban on the retail sale of tobacco products. It seems likely that most customers of a given tobacco retailer live close by, and there are many retailers that carry these products. A restriction imposed on a site even 6.6 kilometers away seems utterly pointless.

If our analysis is appropriate, it would serve to circumscribe the geographic scope of non-competition covenants. Still, our reasoning also reveals some difficult evidential questions. How does one in fact determine what counts as a competition zone? (In Swan, that element was simply asserted by one of the witnesses for Irving.) How can proof be collected? Upon whom should the onus lie? Market conditions are constantly in flux. Could that affect a covenant's validity from time to time? However, even bearing these questions in mind, the analytical framework roughed out here marks an improvement over the existing state of the law. There is currently no principled basis with which to determine if two properties are sufficient proximate.

\section{General Rules Governing the Validity of Private Transactions}

Even if the prerequisites discussed above are met, a covenant may be invalid on some other ground, one that pertains generally to dispositional documents. Three of these are potentially germane to the kind of restrictive covenants under consideration. First, a poorly constructed covenant may be void for uncertainty. (That argument was raised, but failed, in Swan. ${ }^{33}$ ) The standard for certainty applicable for covenants is said to be that used in assessing conditions subsequently attached to land. That test provides that a party subject to a restriction must be able to see clearly and distinctly from the outset as to which acts will constitute a breach. ${ }^{34}$ Paradoxically, this is a very unclear benchmark.

Second, a covenant will be invalid if it imposes an excessive restraint on alienation. In brief, the rules regulating restraints are designed to promote the efficient allocation of property rights. The premise is that land should be able to circulate freely into the hands of those who value it most. Hence, a provision in a deed preventing a parcel from ever being transferred in any way is undoubtedly void. However, limited restrictions imposing some constraint on the mode of

33 Supra note 27.

34 Noble v Alley, [1951] SCR 64, 1950 CarswellOnt 127 (WL Can), applying the test set out in Clavering v Ellison (1859) 7 HL Cas 707, 11 ER 282. 
transfer, the class of potential recipients, and the time during which the restraints are to operate may be valid. It is a matter of degree.

The rules governing restraints on alienation are applicable to direct prohibitions on transfer, such as where a will provides that a devised parcel cannot be sold outside of the family. ${ }^{35}$ These rules can also apply where some stipulation indirectly impedes transferability. So, for instance, a testamentary stipulation that before a property can be sold it must be offered to A at a price well below market value has been held to be invalid. ${ }^{36}$ Although such a stipulation permits transfer, it does so in a way that would severely reduce the likelihood that the owner would choose to sell the property.

One property from the larger study sample is subject to 12 separate restrictions. Can it be said that land has been so excessively encumbered that the net result is an unacceptable restraint on alienation? The answer is probably no. Even if we assume that the total effect of the 12 restrictions is to impose an unacceptable limit on alienation, it is doubtful that a court would assess this set of covenants as a whole. The effect of the doctrine regulating restraints on alienation is to render a transaction invalid. However, here none of the individual covenants creates an excessive restraint. The land has suffered a death by a thousand cuts, none of which would be fatal on its own.

Third, a covenant may fail because it violates some other tenet of public policy. Indeed, there is an ancient doctrine that is extremely pertinent in the present context: the law governing restraints on trade. ${ }^{37}$ Where a restraint on trade is alleged, the concern is that the restrictions have a significant and harmful effect on the market. (Notice that this is the polar opposite of the issue relating to the "touch and concern" and proximity matters discussed above. There, the focus was whether the restrictions had no appreciable impact, to the point that they were a nuisance and undeserving of legal protection.)

In general, a stand-alone contract that seeks to prohibit trade is unenforceable. ${ }^{38}$ Where, however, the restraint is a component of a larger contractual arrangement, such as the sale of a business, reasonable restraints on trade will be enforced. Reasonableness is understood to involve a consideration of the interests of (i) the parties to the contract; and (ii) the public. ${ }^{39}$

If an agreement is prima facie a restraint of trade, the party benefiting must demonstrate that it is reasonable as regards the interests of the parties. If that hurdle is overcome, the onus then falls on the challenging party to show that the public interest would be unduly harmed if the agreement were to be enforced. ${ }^{40}$ Of course, the facets of both parts are multifarious. Speaking in the most general of terms, when a given restraint of trade is assessed, a court will consider whether the

35

36 1995 CarswellOnt 403 (Gen Div); Fuji Builders Ltd v Tresoor, [1984] 5 WWR 80, 1984
CarswellMan 140 (WL Can) (QB).

37

38

39

40

See further Ziff, supra note 9, at 262 et seq.

Re Rosher (1884) 26 Ch D 801. See also Trinity College School v Lyons (1995) 47 RPR (2d) 95,

See generally MJ Trebilcock, The Common Law of Restraint of Trade (Toronto: Carswell, 1986); JD Heydon, The Restraint of Trade Doctrine, 3rd ed (Sydney: LexisNexis Butterworths, 2008).

Vancouver Malt \& Sake Brewing Ltd v Vancouver Breweries Ltd, [1934] AC 181 (PC).

Nordenfelt v Maxim Nordenfelt Guns \& Amunition, [1934] AC 181 (HL).

Herbert Morris Ltd v Saxelby, [1916] 1 AC 688 (HL); Power Motors Ltd v Irving Oil Ltd (1993) 346 APR 290, 1993 CarswellNfld 169 (WL Can) (SCTD). 
prohibitions are overly broad having regard to such factors as the time-period, the scope of the prohibited trade, and the geographic region covered by the agreement.

A discussion of the Canadian law on this topic necessarily involves a review of the English jurisprudence, starting with the House of Lords decision in Esso Petroleum Ltd $v$ Harper's Garage (Stourport) Ltd. ${ }^{41}$ The covenant in Esso involved what is commonly called a tying provision, under which the owner of a garage was obliged to purchase products only from a given supplier (Esso in this case). A question was raised as to whether the doctrine of restraint of trade was applicable - at all -- to restrictive covenants imposed against land.

All five Law Lords presiding over the case issued reasons for judgment. A majority held that the doctrine governing restraint of trade did not apply where a purchaser of land acquires a title that is already impressed with a covenant restraining trade. It was reasoned that in such a situation a purchaser is not surrendering a freedom that was previously held. Prior to owning the land, the would-be purchaser had no right whatsoever to conduct business on that particular parcel. Consequently, no extant right is lost or surrendered by that person. ${ }^{42}$ It followed that the rules governing such restraints would apply where the landowner agreed to a restriction while owner of the servient land. That was in fact the situation in the Esso case. That being so, the opinions expressed by the Law Lords as to pre-existing land covenants was, strictly, obiter dictum.

There are few Canadian cases on point. The most thorough treatment is to be found in the Ontario decision in Stephens $v$ Gulf Oil. ${ }^{43}$ As in Esso, the case involved a tying restriction relating to automotive products. Unlike Esso, however, the key predicate was in place: the party seeking to avoid the tying provisions had acquired the land subject to those terms. The Court of Appeal, while recognizing that the views expressed in Esso were obiter, nevertheless chose to endorse them. As a result, in Ontario the doctrine governing restraint of trade does not apply to a covenant registered on title prior to the acquisition of a parcel, or to a covenant agreed to as part of a purchase. In both situations, no existing freedom has been lost.

A different approach was adopted in the Newfoundland decision of Swan Properties $v$ Irving Oil Ltd. ${ }^{45}$ It will be recalled that the contested restriction in that case prevented the use of the servient lands as a restaurant. Restraint of trade was alleged. On the assumption that the generic rules governing restraints were

41 Esso Petroleum Ltd v Harper's Garage (Stourport) Ltd, [1968] AC 269 (HL).

42 Ibid at 298 (per Lord Reid); at 309 (per Lord Morris of Borth-Y-Guest); at 325 (per Lord Pearce); at 316-7 (per Lord Hodgson). Compare the analysis of Lord Wilberforce at 398. See also Cleveland Petroleum Ltd v Dartstone Ltd, [1969] 1 WLR 116 (CA); Alec Lobb (Garages) Ltd v Total Oil Great Britain Ltd., [1985] 1 WLR 173 (CA); Luminar Lava Ignite Ltd v Mama Group Plc \& Anor, [2009] ScotCS CSOH 68.

43 (1975) 11 OR (2d) 129, 1975 CarswellOnt 809 (WL Can) (CA), leave to appeal refused [1976] 1 SCR xi (note).

44 See also Petro-Canada Inc v Landcorp Ontario Ltd (1988) 50 RPR 126, 1988 CarswellOnt 669 (WL Can) (HC); Denison v Carrousel Farms Ltd, 1981 CarswellOnt 1195 (WL Can), 34 OR (2d) 737 (HC); Hiebert v Pacific Petroleums Ltd, [1980] 3 WWR 72, 1980 CarswellMan 75 (WL Can) (QB) at paras. 9,10. The Esso position has been adopted in Australia Quadramain Pty $v$ Sevastapol Investments Pty, [1976] HCA 10; see further Baramon Sales Pty Ltd v Goodman Fielder Mills Ltd, supra note 27; ACT v Munday, [2000] FCA 653; and in New Zealand: Robinson v Golden Chips (Wholesale Ltd), [1971] NZLR 257 (CA).

45 See the text accompanying notes 27 and 28. 
applicable, the reasonableness of the restriction was assessed by the Court, and based on those criteria the covenant was upheld in its entirety. The covenant worked to create a synergy for Irving Oil in connection with its business plan for the area. Swan's original plan for an office tower comported with Irving's interests and would not have created a conflict had those plans been carried out. The public interest would be served because the overall development would provide a range of complementary services. By contrast, the covenant meant only that Swan was restricted in the operation of only one parcel; it had plenary freedom elsewhere in the town.

While that finding seems cogent, with respect, the case may not have been well-argued. The House of Lords ruling in Esso ${ }^{46}$ is not mentioned, nor is its adoption in Stephens $v$ Gulf Oil. ${ }^{47}$ Rather, the trial judge stated that he had not found any cases that addressed the question of what counts as a restraint of trade within the context of freehold covenants. ${ }^{48}$ Therefore, Swan v Irving cannot be seen as a repudiation of the English doctrine.

The reasoning in Esso has been the subject of criticism. From a technical angle, it could be argued that there is a loss to the owner of the servient land -- but for the promise that owner would have a right that is now no longer tenable. More importantly, one must ask whether allowing such covenants to burden land advances the public interest. If not, nothing should stand in the way of applying the general law regulating restraint of trade.

That alternative approach can be found in American law, which contains no Esso-like doctrine. ${ }^{49}$ Instead, as under the general law, the courts examine the purpose of the covenant, the scope of the business activity being controlled, its geographical and temporal limits, and the countervailing public interest in promoting competition. These are of course very case-specific questions, though some guiding principles can be identified. Generally speaking, a restriction on one parcel will not be regarded as excessive unless the area affected is extensive, or there are few if any alternative properties available in the vicinity that would be suitable for the kind of business involved. At the other extreme, a covenant that is not limited as to time may be found to be ineffective on that ground alone. ${ }^{50}$

The New Jersey decision in Davidson Bros, Inc v D Katz \& Sons, Inc provides a highly relevant illustration of the American position. The case involved a food desert in the decaying downtown core of New Brunswick, NJ. At issue was a covenant imposed on a servient property (the George St land) for the benefit of a nearby lot on Elizabeth St. The restriction was stated to last for 40 years. The servient property was later acquired by the city and, believing that there was a

Supra note 41.

Supra note 43.

Supra note 27 at para 74.

49 See e.g. the lengthy list of authorities cited in Davidson Bros, Inc v D Katz \& Sons, Inc, 579 A 2d 288 (SCNJ, 1990). See also JJ McLoone, "Equitable Servitudes -- A Recent Case and its Implications for the Enforcement of Covenants Not to Compete” (1967-68) 9 Ariz L Rev 441; RL Potts, "Real Covenants in Restraint of Trade -- When do They Run with the Land?" (1967-68) 20 Ala L Rev 114; AM Vann, “Covenant Restricting Use of Land, Made for Purpose of Guarding Against Competition, As Running with Land" 25 American Law Reports 3d 897 (1969, and updates).

50 Cf SE Seitter, “Timeless Matters: Anti-Competition Restrictions in Real Property Deeds” (2007) 63 Journal of the Missouri Bar 191; Hall v American Oil, 504 SW2d 313 (Mo Ct App, 1973). 
serious need for a grocery store in the vicinity, it leased the land at a nominal rent to a private firm for that purpose. That action prompted the holders of the benefit to sue to enforce the covenant.

The Davidson case has a complicated procedural history. In 1990, it had reached the New Jersey Supreme Court, the highest appellate body within the state court system. As part of the reasons for judgment the Supreme Court held that the touch and concern requirement was no longer absolutely essential in determining whether a covenant was capable of running with land in New Jersey. ${ }^{51}$ Instead, reasonableness was the standard to be applied to assess the validity of covenants generally, with restraints on trade being treated as part of that requirement. The Court identified eight factors that should be considered:

1. The intention of the parties when the covenant was executed, and whether the parties had a viable purpose which did not at the time interfere with existing commercial laws, such as antitrust laws, or public policy.

2. Whether the covenant had an impact on the consideration exchanged when the covenant was originally executed. This may provide a measure of the value to the parties of the covenant at the time.

3. Whether the covenant clearly and expressly sets forth the restrictions.

4. Whether the covenant was in writing, recorded, and if so, whether the subsequent grantee had actual notice of the covenant.

5. Whether the covenant is reasonable concerning area, time or duration. Covenants that extend for perpetuity or beyond the terms of a lease may often be unreasonable.

6. Whether the covenant imposes an unreasonable restraint on trade or secures a monopoly for the covenantor. This may be the case in areas where there is limited space available to conduct certain business activities and a covenant not to compete burdens all or most available locales to prevent them from competing in such an activity.

7. Whether the covenant interferes with the public interest.

8. Whether, even if the covenant was reasonable at the time it was executed, "changed circumstances" now make the covenant unreasonable.

51 Davidson Bros, Inc v D Katz \& Sons, Inc, 579 A2d 288 (NJ Super, 1990). But see SF French, "Can Covenants Not to Sue, Covenants Against Competition and Spite Covenants Run With Land? Comparing Results Under the Touch and Concern Doctrine and the Restatement Third, Property (Servitudes)" (2003) 38 Real Prop Prob \& Tr J 267 at 287, suggesting that the ruling is ambiguous on that point, but concluding that "[t]he rules announced in Davidson Bros suggest that the appropriate inquiry would be whether the fact that the benefit is in gross makes the covenant unreasonable".

52 Supra note 51 at 295 (per Garibaldi J). 
With these considerations in place, the matter was sent back to trial. After a protracted hearing, it was held that the covenant created an unreasonable restraint on trade. That finding was upheld on appeal. ${ }^{53}$

The appellate opinion is articulate, nuanced, and persuasive. The closing of the original store had a profound effect on the local residents. There were many lowto moderate-income housing units in the vicinity, many being government projects. Of the more than 3,000 households within the city core, over $26 \%$ were living below the poverty level, compared to $17 \%$ for the city as a whole. Over 700 of these units were located within two blocks of the servient parcel. The closing of the store on that location meant that there was no grocery store within walking distance, creating logistical problems for those residents without a car, and especially for single parents.

Expert evidence was given that the absence of a nearby grocery store increased the cost of food, reduced consumer choice, and adversely affected diet and the overall health of the area residents. In short, the poor were now paying more for less, a result which a government study described as a "perverse irony". ${ }^{54}$ In addition, grocery stores often serve as anchors for other retail operations, drawing customers to a shopping district. Hence it was maintained that, in general, the exodus of supermarkets from inner city areas can diminish the availability of retail operations of all kinds. The city of New Brunswick had made concerted efforts to ameliorate the problem. It attempted, unsuccessfully in the end, to improve transportation alternatives for inner-city residents. Efforts were made to encourage the redevelopment of properties for use as supermarkets, but to no avail. These strategies having produced nothing, the city decided to acquire the servient land, which was purpose-built as a grocery store.

The Court held that the restraint on trade was unreasonable, primarily because the term was excessive and the public interest was adversely affected. The store on the servient property was well-suited for use as a supermarket, and there was no economically viable alternative site in the vicinity. The result was personal hardship to the neighbourhood residents as well as a disruption of the efforts of government and private enterprise to revitalize the inner city. Hence, the Court concluded that in the "absence of any equivalent reciprocal benefit to the city, Davidson's scorched earth policy is so contrary to the public interest in these circumstances that the covenant is unreasonable and unenforceable". 55

The Davidson decision stands as the most dramatic judicial response to restrictive covenants designed to stifle competition. However, there have been other initiatives. The city of Chicago has taken steps to limit the use of covenants affecting supermarkets and drug stores. In 2005, city council passed an ordinance that reduces the scope of non-compete covenants for supermarkets and drug stores of more than 7,500 square feet. The measure recognises that covenants designed to limit competition can be a reasonable response to the relocation of a business to a new site that is proximate to the old one. The ordinance does not apply where the departing owner operates a new location within the city that is (i) no more than one-half mile from the old site; (ii) opened within two years; and (iii) protected by the covenant for no more than three years. Covenants stated to last for one year or

\footnotetext{
Davidson Bros, Inc v D. Katz \& Sons, Inc, 643 A 2d 642 (NJ Super AD, 1994).

Ibid at 646.

Ibid at 648 (per D'Annunzio JAD).
} 
less are fully exempt. The city has the power to extend the scope of an exemption up to one mile and to lengthen the time-period for the opening of the new location up to one year. However, these rules have prospective application only. They do not apply to restrictions in place on the day that the ordinance was formally brought before Chicago's city council. ${ }^{56}$

English law has also addressed the problem. In 2006, the Competition Commission was directed to study competition in the retail grocery sector, and among the topics addressed was the use of non-compete covenants. The commission's report led to the promulgation of an order designed to eliminate existing restrictive covenants and to significantly inhibit the creation of new ones. ${ }^{57}$ The order imposes obligations on a defined set of large grocery retailers; seven firms are named in a schedule. These companies were required to use best efforts to release designated restrictive covenants within six months. The order prohibited the levying of fees of any kind against the owner of the burdened land in relation to the releasing process. The order also prescribed that in instances where the six-month time period had not been met, the retailer was required to sign a declaration that it will not enforce the covenant.

Another storm may be brewing in England, involving that most cherished of English institutions, the local pub. There are about 57,000 public houses in the country. It is hard to conceive of a neighbourhood or village, no matter how small, without one. Some are part of a national chain, others regional, and some are individually owned. However, for a host of reasons, the number of pubs has declined in recent years. From 2004 to 2009, almost 600 pubs were sold subject to restrictive covenants. It is a staggering figure, although the imposition of covenants was not a standard procedure. There were over 6,600 pubs sold by the large chains over the study period, so that covenants were used in only $9.1 \%$ of sales. One firm, Marston's, imposed a covenant in only one of its 426 sales. Enterprise Inns was the most active in this regard, annexing covenants in $19 \%$ of its transfers, though under its current code of practice covenants are no longer to be imposed. The question of whether a governmental response is required is under review.

More generally, in 2010 the scope of the English Competition Act was expanded so as to apply to restrictive covenants. Prior to that year, a wide range of land agreements were excluded from the ambit of the legislation. The revocation of that exclusion means that restrictive covenants in restraint of trade can be challenged under the statute, and so fall to be considered with reference to general competition principles. ${ }^{60}$ Canadian competition law also contains relevant provisions, which on their face can apply to restrictive covenants. Under that regime a business may be found to have acted in abuse of a dominant position in the market where (i) it is substantially or completely in control of a class of

56 City of Chicago Zoning Ordinance 17-1-1004. Negative Use Restrictions Prohibited as Against Public Policy. [Copy on file at the University of Alberta.]

57 Groceries Market Investigation (Controlled Land) Order 2010, art 5. There are various exceptions contained within arts 4, 5, 6, 9, 10.

58 Art 4. See also articles 7 and 8 , which deal with exclusivity agreements.

59 Department for Communities and Local Government, The Use of Restrictive Covenants in the Pub Industry and Their Impact on Local Communities (London, Department for Communities and Local Government, 2011).

60 Competition Act, 1998 (UK), c 41. 
business; (ii) has engaged in anti-competitive acts; and (iii) those acts have or are likely to prevent or lessen substantially competition. ${ }^{61}$ Factors (i) and (iii) pose considerable hurdles, particularly when a single restrictive covenant is challenged. However, if a firm has registered a large number of covenants in a given market (whatever that might be taken to mean), it would seem plausible that such anticompetitive action would be assessed as a whole. At the moment we do not know. It is doubtful that such a line of attack has been put to the test in Canada, even in relation to the supermarket covenants.

\section{Ex Post Termination (and Modification)}

A covenant may be terminated in a variety of ways. Some may end simply by virtue of the expiration of a built-in time limitation. As we have seen above, most of the sample covenants contained a fixed duration or a formula to mark the lifespan of the interest. Even after creation, the owner of a benefit may forego it, either by agreement or by a unilateral surrender. As a general rule, if the servient tenement and dominant tenements fall under the ownership of one party, the covenant ends.

When the servient tenement has been transferred, enforcement against the new owner is dependent on equitable remedies, for only equity recognizes that the burden of a restrictive covenant can run with land. That being so, equitable relief may be denied when the owner of the benefit has acquiesced in some way to the breaches or has merely delayed in seeking a remedy. A remedy will be also denied where the covenant has become obsolete. That principle has been called into play where the general nature of a neighbourhood has so changed over time that the covenant has become pointless. ${ }^{62}$

Some of the equitable doctrines have been codified and, arguably, supplemented in several provinces. Under statute in British Columbia, ${ }^{63}$ a covenant may be terminated or modified where it has become obsolete, where it is invalid, ${ }^{64}$ has expired, or where the parties have expressly or impliedly agreed to termination or modification. These provisions do little to alter the pre-statute law.

However, the legislation also enables a court to intervene in two closely related circumstances: first, "where the reasonable use of the land will be impeded, without practical benefit to others"; and second, where an order "will not injure the person entitled to the benefit." ${ }^{65}$ Likewise in Alberta, there is a power to intervene where that would be "beneficial to the persons principally interested in its enforcement." Similar language is used in Ontario, Nova Scotia and New Brunswick. ${ }^{66}$ On its face, the function of this kind of ground is obscure. If removal of the covenant is desired by those holding the benefit, that may be done without judicial intervention. Alternatively, these provisions might be taken to mean that a court may impose its view on what is in the best interests of the holder of the benefit, even if that is contrary to the subjective preferences of that person. Case

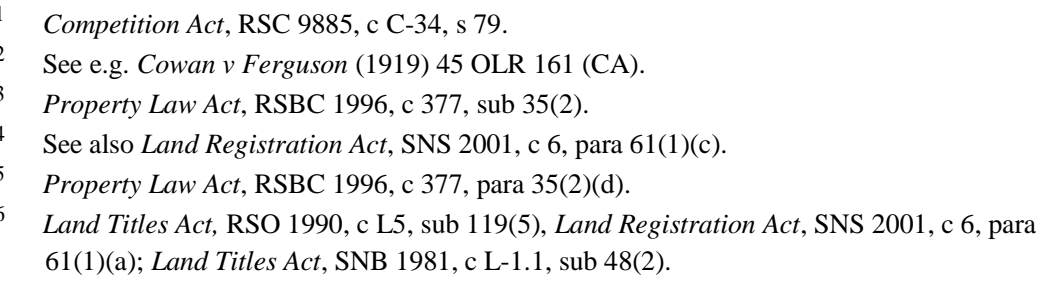


law in Alberta suggests that such a reading is not appropriate, and that a court "should not act the part of a benevolent despot" in deciding what is best for the holder of the benefit. In Ontario, the power to terminate on this ground has been invoked when enforcement would be "clearly vexatious". ${ }^{68}$ It would also seem relevant in the case of a large scale building scheme, in circumstances where most -- but not all -- of the parties wish to terminate the restriction. In that case termination can be ordered to override a contrary view held by a few holdouts.

Statutory provisions in Alberta, Nova Scotia, and New Brunswick provide further that an order for revision or termination may also issue if the covenant conflicts with zoning laws or other regulatory instruments. ${ }^{69}$ Such a power would seem to provide the broadest ex post power of a court to alter a covenant where a tension exists between the private covenant and some facet of the public interest. However, this ground of attack is in fact extremely limited. All of the covenants in our study contain provisions that are, on one view, in conflict with a governing bylaw. In all cases, it is safe to assume that the applicable zoning by-law allows for a range of commercial activity. The restrictive covenants studied here reduce the number of allowable commercial uses that would otherwise be permissible under zoning.

If that is the kind of conflict contemplated by the provision, then it would seem that all restrictive covenants would inherently be in conflict. The function of the restrictive covenants is to produce a more refined limit than that offered by zoning. In fact, the required conflict has been defined far more narrowly. It has been held that an operative conflict arises only when adherence to a covenant necessitates a violation of a by-law. In other words, a conflict arises when compliance with both sets of rules, private and public, is not possible. A restriction on one kind of business activity within an area that is zoned for commercial use does not produce the necessary conflict because myriad other commercial uses remain possible.

In sum, it can be seen that the bases for ex post alteration of a restrictive covenant are narrow. There is, nevertheless, one state response that can be marshalled to eliminate (valid) restrictive covenants that are viewed as clashing with the public interest. Such a covenant can be terminated through expropriation. All provinces have legislative schemes for the expropriation of private property by designated governmental bodies, and all of these regimes call for compensation in favour of the expropriated owner. The extinction of the benefit of a restrictive covenant should qualify as a compensable taking. Discharge would come at a (hard-to-quantify) price. ${ }^{70}$

67 Re Grieve (1953) 10 WWR (NS) 49, 1953 CarswellAlta 2 (WL Can) (SC) at 54 (per Egbert J).

69 It is odd if the section is saying that a true conflict with public planning is a necessary, but not sufficient, condition for a court order terminating or modifying the covenant, because it must also be determined that the order would be in the public interest. The wording seems to imply that not all true conflicts with public planning instruments will be remedied.

70 In addition, in principle, a province might seek to extinguish such rights with no or inadequate compensation. There is no entrenched right under Canadian law against such action. A guarantee of compensation for foreign investors may exist under treaty, as exists for American and Mexican investors under article 1110 of the North American Free Trade Agreement [NAFTA]. See further B Ziff, “"Taking' Liberties: Protections for Private Property in Canada" in E Cooke, ed, Modern Studies in Property Law, vol 3 (Oxford: Hart, 2005) 341. 


\section{CONCLUSION}

In this article we have examined the use of restrictive covenants as part of a business model designed to reduce competition. Our foray into the land titles registry in Edmonton confirmed that this strategy is found in use in a wide range of retail fields. In at least one setting -- in relation to neighbourhood grocery stores -- a demonstrable harm has been claimed. Our review of the law suggests that as matters now stand there is little that can be done in response to these concerns. In theory, there are many bases upon which the ongoing validity of a restrictive covenant might be contested. The two most germane grounds for doing so relate to the proximity requirement and the doctrine of restraint of trade. However, the limits imposed by the requirement of proximity are not well-defined, and the doctrine of restraint of trade, at least to the extent Canadian law adheres to the English position, offers very little assistance.

The city of Edmonton has been grappling with this reality in recent years, in response to grocery store covenants and their contribution to the emergence of food deserts. A report completed in 2012 offered several possible responses. One would involve reform of Alberta law governing the judicial power to modify or discharge covenants. The proposed amendment would broaden the meaning of what counts as a conflict between a restrictive covenant and a municipal instrument, thereby increasing the scope for judicial intervention. Another proposal calls for delegating to municipalities the authority to impose time limits on covenants (as has been done in Chicago), or more broadly, conferring on local authorities the ability to respond to restrictive covenants that interfere with municipal powers. A third option is for the city to exercise its power of expropriation to acquire those covenants that are seen as preventing neighbourhood supermarkets.

The other assorted anti-competitive covenants studied in this paper appear to be more innocuous. The world hardly suffers because donuts or even gasoline cannot be sold on a given corner lot. Such a restriction is no worse than a nuisance. Even so, at some point in the future -- 25, 50, 75, or a 100 years from now -- the layering of covenants may become so problematic that the costs of reviewing title or seeking the removal of outmoded restrictions will unnecessarily hamper land sales. If so, measures may be needed to rectify the problem. Change in the law of property is typically slow because reducing or eliminating property entitlements almost inevitably means that the investment-backed expectations of current owners will be disrupted. ${ }^{72}$ That being so, perhaps now is the time to establish a regime that will govern future private covenants in a way that protects and advances the public interest.

71 G Beck \& J Johnson, "Restrictive Covenants and Zoning Processes", Sustainable Development Report 2012SCP0003, 25 January 2012.

72 See further B Ziff, "Yet Another Function of the Numerus Clausus Principle of Property Rights, And a Useful One at That" online: SSRN <http://ssrn.com/abstract=2026088>. 


\section{APPENDIX \\ SPECIMEN RESTRICTIVE COVENANTS}

\begin{tabular}{|c|c|c|c|c|c|}
\hline DOCUMENT & RESTRICTION & TIME & DT & & COMMENTS \\
\hline $5730 \mathrm{KM}$ & $\begin{array}{l}\text { Petroleum and gas products, retail or } \\
\text { wholesale }\end{array}$ & 25 & 1 & $1 \mid$ & Expired in 1982 \\
\hline $1555 \mathrm{UF}$ & Only as a hotel or motel & -- & 1 & 11 & Registered in 1973 \\
\hline 782154676 & Petroleum fuels, retail or wholesale & $\mathrm{F}$ & 1 & 1 & \\
\hline 912091973 & Cinema or motion picture theatre & 40 & 1 & $1 \mid$ & DT is a leasehold estate \\
\hline 932222740 & Home improvement or garden centre & $\mathrm{F}$ & 1 & 1 & \\
\hline 932335982 & $\begin{array}{l}\text { Licensed lounge; pizzeria; video arcade; tea, } \\
\text { coffee, yoghurt, sandwich, donut, muffin } \\
\text { shops }\end{array}$ & -- & 1 & 1 & \\
\hline 942147139 & Major department or retail foodstore & -- & 1 & 1 & \\
\hline 952268042 & Muffler shop and related automobile services & 40 & 1 & 1 & \\
\hline 962252503 & $\begin{array}{l}\text { Food, tobacco, pharmaceuticals, service, } \\
\text { parking for such businesses }\end{array}$ & -- & 7 & 1 & \\
\hline 972187284 & Hardware store & F & 1 & 4 & Royal lives clause \\
\hline 982053521 & Porn shop, massage parlour, strip club & -- & 5 & $5 \mid$ & Reciprocal covenants \\
\hline 992210393 & Food store, drug store, convenience store & $\mathrm{F}$ & 3 & 1 & \\
\hline 002048987 & Gas bar or liquor store & -- & 1 & 10 & $\begin{array}{l}\text { Covenant by vendor, } \\
\text { burdening land retained } \\
\text { by vendor }\end{array}$ \\
\hline 002290445 & Bookstore & $?$ & $?$ & $?$ & $\begin{array}{l}\text { Caveat; full covenant } \\
\text { not appended }\end{array}$ \\
\hline 012026196 & $\begin{array}{l}\text { Primary business is the sale of coffee, } \\
\text { donuts, "Tom Bits", bagels, sandwiches, etc. }\end{array}$ & -- & 1 & 1 & \\
\hline 012361408 & $\begin{array}{l}\text { Office Depot or successor if carrying on the } \\
\text { sale of business supplies, etc. }\end{array}$ & F & 1 & 19 & \\
\hline 022208314 & Electronics & $\mathrm{F}$ & 1 & 1 & \\
\hline 022365072 & $\begin{array}{l}\text { Banking services of any kind including } \\
\text { ATM }\end{array}$ & 10 & 1 & 1 & \\
\hline 032424595 & $\begin{array}{l}\text { Regional shopping centre or department } \\
\text { store }\end{array}$ & -- & 4 & \begin{tabular}{|l|}
1 \\
\end{tabular} & \\
\hline 052353535 & Casino & $30 \mathrm{~F}$ & 1 & 1 & $\begin{array}{l}30 \text { years is the } \\
\text { maximum duration }\end{array}$ \\
\hline 082269517 & Butcher shop and grocery store & 15 & 1 & 3 & \\
\hline 092275842 & Convenience store and liquor store & -- & 1 & 1 : & ST is a leasehold \\
\hline
\end{tabular}

\section{NOTE}

The covenants are listed in the Table above in chronological order. In general, under registration protocols, the first two digits in a registration number denoted the year of registration (e.g., a document starting with 96 was registered in 1996). The identifier for second covenant listed in the Table does not follow that protocol. As noted above, it was registered in 1973.

\section{LEGEND}

"ST" denotes servient tenement.

"DT" denotes dominant tenement.

"F" denotes that the duration is fixed by a formula.

A number in the "Time" column denotes the stated number of years for which the covenant was to operate. 